EMPOWER: Jurnal Pengembangan Masyarakat Islam

Vol. 5, No. 2, Desember 2020, hlm. 1-20

e-ISSN: 2580-0973, p-ISSN: 2580-085X

Tersedia online di: http://syekhnurjati.ac.id/jurnal/index.php/empower

Email: empowerjurnal@gmail.com

\title{
Pendampingan UP2K Kemuning Dalam Pemberdayaan Usaha Mikro Keluarga di Kelurahan Muncul Tangerang Selatan
}

\author{
Aya Aisyah* \\ (Program Studi Kesejahteraan Sosial Fakultas Ilmu Dakwah dan Ilmu Komunikasi \\ Universitas Islam Negeri (UIN) Syarif Hidayatullah Jakarta) \\ Email: suratuntukaya@gmail.com

\section{Muhtadi**} \\ (Program Studi Pengembangan Masyarakat Islam Fakultas Ilmu Dakwah dan Ilmu \\ Komunikasi.Universitas Islam Negeri (UIN) Syarif Hidayatullah Jakarta) \\ Email: muhtadi@uinjkt.ac.d
}

\section{Article History}

Submitted: 12.05.2020, Revised: 08.12.2020, Accepted: 12.12 .2020

\begin{abstract}
The UP2K program is one of the government programs aimed at women and prioritized only for those who are less fortunate or have minimal capital to open a business or develop their business. This study wanted to know the extent of the impact and role of the program on the community empowerment process in Muncul Village, Setu District, South Tangerang City. The research method used in this study was a qualitative method. The results of his research show that the UP $2 \mathrm{~K}$ Program has an important role in community empowerment in Muncul Village. On the other hand, there are four roles that the program plays, namely enabler, broker, educator, and social planner. As for the impact, there are three impacts, namely, the impact administratively, economically, and socially. The novelty of this research is that the recipients of the UP $2 \mathrm{~K}$ program are starting to become less dependent on mobile banks or loan sharks.
\end{abstract}

Keywords: program impact, program role, UP $2 \mathrm{~K}$ 


\begin{abstract}
Abstrak
Program UP2K merupakan salah satu program pemerintah yang ditujukan untuk kaum perempuan dan hanya diprioritaskan kepada mereka yang kurang mampu atau minim modal untuk membuka usaha atau mengembangkan usahanya. Penelitian ini ingin mengetahui sejauh mana dampak dan peran dari program tersebut pada proses pemberdayaan masyarakat di Kelurahan Muncul Kecamatan Setu Kota Tangerang Selatan. Metode penelitian yang digunakan pada penelitian ini adalah metode kualitatif. Adapun hasil penelitiannya bahwa Program UP2K memiliki peran yang cukup penting dalam pemberdayaan masyarakat di Kelurahan Muncul. Di sisi lain, terdapat empat peran yang dimainkan oleh program tersebut, yaitu enabler, broker, educator, dan social planner. Adapun dampaknya, terdapat tiga dampak yaitu, dampak secara administratif, secara ekonomi, dan secara sosial. Kebaruan dari penelitian ini bahwa para penerima program UP2K mulai berkurang ketergantungan kepada bank keliling atau rentenir.
\end{abstract}

Kata Kunci: dampak program, peran program, UP2K

\title{
PENDAHULUAN
}

Indonesia memiliki pertumbuhan populasi yang tinggi dan cepat diperkirakan pertumbuhan penduduk yang mencapai 1,3\% bahkan lebih. Menurut Badan Pusat Statistik, banyaknya warga miskin di Indonesia pada per bulan September tahun 2018 mencapai 9,66\%.1 Sehingga membuat tingkat kesejahteraan pendidikan, ekonomi, kesehatan dan lingkungan yang dewasa ini sangat memprihatinkan. Keadaan ini tentunya menjadi perhatian tersediri oleh pemerintah, sehingga diperlukan usaha yang sangat signifikan untuk menekan angka kemiskinan. Dengan demikian pemerintah berusaha membuat program untuk meningkatkan kesejahteraan keluarga yang subyeknya dari masyarakat oleh masyarakat dan untuk masyarakat dengan tujuan dapat meningkatkan ekonomi dalam keluarga. ${ }^{2}$ Program ini tentunya diharapkan dapat memberikan dampak kepada kesejahteraan

\footnotetext{
${ }^{1}$ Badan Pusat Statistik, 'No Title'

<www.bps.go.id/pressrelease/2019/01/15/1549/persentate-penduduk-miskin-padaseptember-2018-sebesar-9-66-persen.html> [accessed 20 January 2019].

2 Siti Asripah, 'Peranan Posdaya Dalam Meningkatkan Kesejahteraan Keluarga Di Masyarakat', DEMOCRATIA, 1.1 (2013), p. 78.

EISSN:2580-0973 I ISSN: 2580-085X
} 
masyarakat khususnya keluarga.

Kemiskinan, menurut Itang disebabkan oleh dua faktor, yaitu faktor internal dan eksternal. ${ }^{3}$ Untuk faktor internal, Itang membagi kembali menjadi 6 (enam), yaitu sikap, pengalaman, kepribadian, konsep diri, motif, dan persepsi. Kemiskinan pada akibatnya memiliki dampak bagi orang yang menyandangnya dan beberapa dampak atau akibat dari kemiskinan, di antaranya. ${ }^{4}$ Pertama, pengangguran yang dikarenakan sulitnya mendapat pekerjaan, menjadikan tidak adanya pendapatan yang membuat pemenuhan kebutuhan sulit dicapai, kekurangan nutrisi dan kesehatan, dan tak dapat memenuhi kebutuhan penting lainnya.

Kedua, putus sekolah. Putus sekolah dan hilangnya kesempatan pendidikan akan menjadi penghambat rakyat miskin dalam menambah keterampilan, menjangkau cita-cita dan mimpi mereka.

Ketiga, kesehatan yang sulit didapatkan. Kesehatan yang sulit untuk didapatkan karena kurangnya pemenuhan gizi sehari-hari akibat dari kemiskinan. Hal ini membuat rakyat miskin sulit menjaga kesehatannya. Belum lagi ditambah biaya pengobatan yang mahal di klinik atau rumah sakit yang tidak dapat dijangkau masyarakat miskin, sehingga kesehatan menjadi hal yang sangat mahal bagi masyarakat miskin.

Keempat, kriminalitas. Kriminalitas merupakan dampak lain dari kemiskinan. Kesulitan mencari nafkah mengakibatkan orang lupa diri sehingga mencari jalan cepat tanpa memedulikan halal atau haramnya uang sebagai alat tukar guna memenuhi kebutuhan. Masyarakat akan menggunakan cara apapun untuk memenuhi kebutuhannya.

Kelima, buruknya generasi penerus. Buruknya generasi penerus adalah dampak yang berbahaya akibat kemiskinan. Jika anak-anak putus sekolah dan bekerja karena terpaksa, maka akan ada gangguan pada anakanak itu sendiri. Gangguan itu seperti gangguan pada perkembangan mental, fisik dan cara berfikir mereka, sehingga akan menghambat berkembangnya anak itu sendiri.

Dari kelima dampak kemiskinan menjadikan kemiskinan dan ketimpangan pendapatan adalah masalah sosial yang harus diselesaikan

\footnotetext{
${ }^{3}$ Itang Itang, 'Faktor Faktor Penyebab Kemiskinan', Tazkiya, 16.01 (2017), 1-30 (pp. 79).

4 Itang.

EISSN:2580-0973 | ISSN: 2580-085X
} 
dan menjadi tanggung jawab bersama, baik pemerintah, swasta, dan organisasi masyarakat sipil. Dari sisi peran pemerintah berbagai program dan kebijakan pembangunan telah dilakukan untuk memacu pertumbuhan ekonomi, namun ini tidak serta merta dapat menyelesaikan masalah sosial tersebut secara komperhensif. Karena memang diperlukan kerjasama dari berbagai aspek demi menunjang kebijakan dan program yang diberikan.

Menurut Yunus, pada dasarnya pemerintah dapat melakukan banyak hal untuk menyelesaikan masalah sosial karena kemampuannya dalam mengakses dan mengelola sumber daya. Salah satu upaya penyelesaian masalah sosial adalah dengan wirausaha sosial yang menggunakan metode pendekatan kewirausahaan. Kegiatan ini merupakan terobosan yang luar biasa, karena memang kepedulian pemerintah sangat diperlukan untuk memperbaiki angka kemiskinan. ${ }^{5}$

Kepedulian pemerintah dalam upaya penanggulangan kemisikinan diwujudkan dengan adanya beberapa kebijakan pemberdayaan ekonomi bagi keluarga miskin yang diprogramkan pemerintah sebagai salah satu langkah yang efektif dalam upaya penanggulangan kemiskinan baik melalui kelembagaan yang bersifat lembaga department maupun non departemen. ${ }^{6}$

Dalam Undang-undang No 11 Tahun 2009 tentang Kesejahteraan Sosial Pasal 1 ayat 10 yang berbunyi, Pemberdayaan sosial adalah semua upaya yang diarahkan untuk menjadikan warga negara yang mengalami masalah sosial mempunyai daya, sehingga mampu memenuhi kebutuhan dasarnya.

Pemberdayaan sebagai perubahan ke arah yang lebih, dari tidak berdaya menjadi berdaya. Pemberdayaan terkait dengan upaya peningkatan taraf hidup ke arah yang lebih baik. Pemberdayaan adalah meningkatkan kemampuan dan rasa diri untuk menggunakan daya yang dimiliki dalam menentukan tindakan ke arah yang lebih baik. Menurut Payne mengemukakan bahwa pemberdayaan ditunjukkan guna membantu klien memperoleh daya untuk mengambil keputusan dan menentukan

\footnotetext{
${ }^{5}$ Suharyanto, Motivasi Masyarakat Untuk Pengembangan Kewirausahaan, Dalam DimensiDimensi Masalah Sosial Dan Pemberdayaan Masyarakat (Yogyakarta: APMD Press, 2005), p. 157.

${ }^{6}$ Strategi Pemberdayaan Masyarakat (Edisi Revisi) (Bandung: Utama Press, 2010). EISSN:2580-0973 I ISSN: 2580-085X
} 
tindakan. ${ }^{7}$ memungkinkan perkembangan dan penggunaan kemampuan terpendam dalam setiap individu.

Program Usaha Peningkatan Pendapatan Keluarga (UP2K) merupakan respons pemerintah yang bertujuan menyelesaikan gejala kemiskinan pada aspek pengangguran. Program ini diharapkan mampu meningkatkan kesejahteraan dan ketahanan keluarga yang dicerminkan oleh meningkatnya kemampuan keluarga dalam memenuhi kebutuhan keluarga. Program UP2K merupakan salah satu program pemerintah yang ditujukan untuk kaum perempuan dan hanya diprioritaskan kepada mereka yang kurang mampu atau minim modal untuk membuka usaha atau mengembangkan usahanya. Mereka tidak mampu untuk meningkatkan pendapatan mereka, atau lebih tepatnya pendapatan mereka hanya cukup untuk memenuhi kebutuhan sehari-hari, tanpa adanya penambahan modal dari pendapatan mereka.

Kecamatan setu kelurahan Muncul kota Tangsel merupakan kecamatan yang terpilih untuk ikut bersaing dalam 6 produk unggulan secara nasional. Kelurahan ini sudah memasuki penyeleksian yang cukup ketat dan PKK Kemuning berhasil menjadi juara memenangkan perlombaan hingga tingkat provinsi Banten. Menurut Wakil Walikota Tangerang Selatan, Benyamin Davine, peran Tim Penggerak PKK sangat aktif dalam menyukseskan berbagai pembangunan di Kota Tangerang Selatan. Menurutnya, secara khusus Pemerintah Kota Tangerang Selatan memposisikan kaum wanita sebagai bagian dari konsep pembangunan Kota Tangerang Selatan. ${ }^{8}$

"Sebagai bagian dari konsep pembangunan, PKK ini memiliki peran yang luar biasa. Kadang PKK bisa berbuat hal-hal yang tak bisa disentuh oleh Pemkot. Kami sangat apresiasi kepada kelurahan Muncul masuk dalam kategori nasional," ungkapnya di Kantor Kelurahan Muncul Senin (31/7).

\footnotetext{
${ }^{7}$ Diana Apriliza, 'Faktor-Faktor Penghambat Dalam Pelaksanaan Program Pemberdayaan Keluarga Untuk Orang Tua Anak Jalanan (Studi Kasus Pada Orang Tua Penerima Bantuan Stimulan Modal Usaha Pada Pusat Pengembangan Pelayanan Sosial Anak/P3SA Bambu Apus' (Universitas Indonesia, 2012), p. 43.

8 'No Title', Tangerangexpres.Co.Id, 20 January 2019.

EISSN:2580-0973 I ISSN: 2580-085X
} 
Dalam agama Islam sendiri, keharusan menolong bagi orang yang kurang mampu terdapat pada beberapa ayat, salah satunya ada pada surat An-Nisa ayat 8 yang berbunyi:

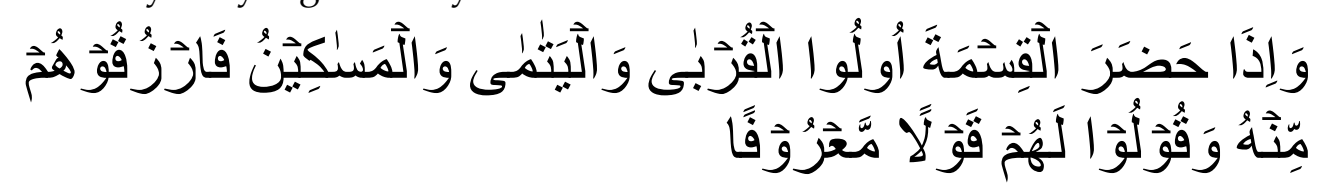

Artinya: "Dan apabila pada waktu pembagian itu hadir beberapa kerabat, anak-anak yatim dan orang miskin, maka berilah mereka dari sebagian dari harta itu dan ucapkanlah perkataan yang baik kepada mereka" (Q.S AnNisa: 8)

Dari hasil pengkajian peneliti, peneliti ingin mengangkat bagaimana peran dan cara dari program Usaha Peningkatan Pendapatan Keluarga (UP2K) dalam menurunkan angka kemiskinan pada aspek pengangguran. Peneitian ini diangkat mengingat program Usaha Peningkatan Pendapatan Keluarga merupakan program yang sudah sukses di beberapa tempat. Berdasarkan temuan beberapa penelitian di luar penelitian ini, Usaha Peningkatan Pendapatan Keluarga (UP2K) bisa membantu usaha-usaha yang sedang dijalankan oleh masyarakat yang ada dinaungannya.

Selain itu, peneliti melihat belum adanya penelitian yang dilakukan mengenai Program UP2K di Kemuning, membuat peneliti ingin meneliti dampak serta peran yang dijalankan oleh program tersebut yang sudah sangat berkembang.

Metode yang digunakan pada penelitian ini adalah metode kualitatif. Penelitian kualitatif adalah penelitian yang bermaksud untuk memahami fenomena tentang apa yang dialami oleh subjek penelitian misalnya perilaku, persepsi, motivasi, tindakan, dll, secara holistik, dan dengan cara deskripsi dalam bentuk kata-kata dan bahasa, pada suatu konteks khusus yang alamiah dan dengan memanfaatkan berbagai metode alamiah. ${ }^{9}$

Adapun teknik pengumpulan data pada penelitian ini dilakukan dengan menggunakan teknis wawancara mendalam guna memperoleh pemahaman yang mendalam dan menyeluruh. Serta data sekunder berupa

\footnotetext{
${ }^{9}$ Lexy J Moleong, Metode Penelitian Kualitatif(Bandung: PT Remaja Rosdakarya, 2011), p. 6.
}

EISSN:2580-0973 I ISSN: 2580-085X 
observasi dan informasi dari kerabat informan. Teknik pemilihan informan dalam penelitian ini adalah purposive sampling yang memberikan keleluasaan kepada peneliti dalam menyeleksi informan yang sesuai dengan tujuan penelitian. Sedangkan lokasi penelitian yang dipilih di UP2K Kelurahan Muncul Kecamatan Setu Kota Tangerang Selatan. Analisis data dalam penelitian ini melalui membaca dan meninjau data (catatan observasi, transkip wawancara) dan akhirnya dapat menganalisis temuantemuan dari penelitian ini. ${ }^{10}$

\section{HASIL DAN PEMBAHASAN}

\section{Analisis Peran dan Pihak yang Terlibat Program UP2K}

Usaha Peningkatan Pendapatan Keluarga (UP2K) merupakan program yang bertujuan memberdayakan usaha rumahan masyarakat yang masih membutuhkan bantuan untuk bisa meningkatkan usaha tersebut. Program UP2K di Kelurahan Muncul ini sudah berjalan sejak tahun 2014. Berdasarkan hasil wawancara peneliti dengan beberapa usaha rumahan yang masih atau sudah pernah mengikuti program UP2K, peneliti menemukan beberapa peran yang dipakai untuk pemberdayaan masyarakat pada program ini.

Menurut Sembiring fungsi pemerintah negara termasuk pemerintah daerah dimanapun berada, sekurang-kurangnya melakukan fungsi pelayanan (services), fungsi pengaturan (regulation), dan fungsi pemberdayaan (empowering), dalam upaya mewujudkan tata kelolah pemerintahan yang baik (good governance). ${ }^{11}$ Sementara menurut Hamdi fungsi pemerintah yakni melakukan pengaturan dan memberikan pelayanan. ${ }^{12}$ Pengaturan dalam arti menegaskan bingkai kesepakatan kehidupan kolektif, agar terdapat kepastian dan perilaku yang memberikan kemanfaatan pada kepentingan umum. Pemerintah memberikan regulasi untuk mengatur dalam pelayanan kepada masyarakat, sehingga pemerintah menjadi kunci dalam pelaksanaan program.

\footnotetext{
${ }^{10}$ Emzir, Metodologi Penelitian Kualitatif (Jakarta: Rajawali Pers, 2011), p. 37.

${ }^{11}$ Muhammad Nurdin, Sitti Nurmaeta, and Muhammad Tahir, 'Peran Pemerintah

Daerah Dalam Pemberdayaan Masyarakat Petani Jagung Di Kecamatan Biringbulu Kabupaten Gowa', Otoritas: Jurnal Ilmu Pemerintahan, 4.1 (2014), p. 70.

12 Nurdin, Nurmaeta, and Tahir.

EISSN:2580-0973 I ISSN: 2580-085X
} 
Program UP2K-PKK (Usaha Peningkatan Pendapatan Keluarga Pemberdayaan dan Kesejahteraan Keluarga) merupakan gerakan nasional dalam bidang pemberdayaan masyarakat yang dalam pelaksaanaannya dari, oleh, dan untuk masyarakat. Sehingga pemanfataanya dapat dirasakan langsung oleh masyarakat. Gerakan ini merupakan salah satu implementasi kebijakan bidang pemberdayaan wanita dari segi perekonomian. Hal ini dikarenakan dengan meningkatnya kebutuhan dan keadaan menjadikan wanita sangat perlu diberdayakan dalam membantu peningkatan kesejahteraan keluarga.

Program UP2K adalah segala kegiatan ekonomi yang diusahakan oleh keluarga, baik secara perorangan maupun kelompok, yang modalnya bersumber dari swadaya masyarakat, bantuan pemerintah, bantuan luar negeri, swasta, serta sumber lain yang sah dan tidak mengikat. Program ini bergerak dalam usaha ekonomi keluarga yaitu suatu bentuk kegiatan usaha yang dilakukan oleh keluarga, bertujuan meningkatkan pendapatan keluarga dalam rangka mewujudkan kesejahteraan keluarga. Sehingga, peran keluarga terutama wanita menjadi memiliki peran penting dalam peningkatan kesejahteraan.

Pada konteks ini, untuk mengetahui program UP2K memiliki peran yang sangat membantu masyarakat sehingga mencapai masyarakat yang terberdayakan dari segi ekonomi. Penulis menganalisis peran dari orangorang yang terlibat pada program ini. Dengan harapan akan mengetahui peran program pada pemberdayaan masyarakat yang memiliki dampak mendorong peningkatan perekonomian keluarga. Karena sebuah program tidak akan berjalan dengan baik tanpa adanya petugas pengembangan masyarakat yang hadir membantu dalam permberdayaan masyarakat.

Berdasarkan hasil wawancara dengan Pak Mahmudin yang mengatakan bahwa: ${ }^{13}$

"Program ini berperan untuk mempercepat untuk membawa perubahan kepada masyarakat. Namun tata cara mempercepatnya dengan cara memberdayakan. Sehingga masyarakat juga paham tata kerja dan peran dari program ini. Tapi program ini gak bisa jadi pemercepat perubahan, kalau dari yang merencakan sama pelaksananya gak bagus."

\footnotetext{
13 Wawancara Pribadi dengan Pak Mahmudin selaku Plt. Kasi. Kesos. Kecamatan Setu pada tanggal 23 September 2019 pada pukul $10.00 \mathrm{WIB}$

EISSN:2580-0973 I ISSN: 2580-085X
} 
Namun program ini tidak akan berjalan dengan maksimal jika subjek pelaksananya tidak paham akan peran dari program tersebut. Sehingga peran sebagai perencana sosial (social planner) juga melekat dengan para pihak pelaksana. Berdasarkan hasil penelitian di lapangan, terdapat beberapa pihak yang bertanggung jawab atas terlaksananya program ini. Hal tersebut peneliti temukan saat melakukan wawancara dengan Pak Mahmudin, peneliti menemukan beberapa peran dari pihak-pihak yang terlibat dan bertanggung jawab atas program UP2K. Beliau mengatakan bahwa: ${ }^{14}$

"Pihak-pihak yang bertanggung jawab atas program ini adalah kecamatan, yang berperang sebagai monitoring program. Kemudian kelurahan itu sebagai perantara dan juga pelaksana program. Ya tentunya sebagai perencana juga yah. Soalnya kelurahan itu perantara dari Pemerintah Kota ke masyarakat dan juga berperan sebagai pelaksana program. Jadi kelurahan mempunyai 2 (dua) peran."

Hal sama peneliti temukan saat melakukan wawancara dengan Ibu Saumi yang menyatakan bahwa:

"Program ini sangat berperan sekali bagi kami yang ingin mengembangkan usaha. Tapi menurut saya, peran Ibu Lurah dan kelompok PKK juga sangat membantu. Ibu Lurah itu yang merencanakan program ini harus dijalankan seperti apa. Sehingga menurut saya, orang-orang di kelurahan juga memiliki peran juga sehingga program ini bisa berjalan dan memberikan dampak ke para pengusaharumahan."

Selain itu, peran lain dari para pihak yang terlibat pada program ini adalah sebagai perantara (broker) dan pendidik (educator). Berdasarkan hasil wawancara dan observasi di lapangan, peneliti menemukan bahwa pada saat pelaksanaan ditahap awal kelurahan dan kelompok PKK melakukan pelatihan terlebih dahulu. Tujuannya untuk memberikan kesadaran terhadap masyarakat di Kelurahan Muncul. Selain itu, bertujuan untuk memberikan pengetahuan dan ketrampilan lebih kepada para pengusaha yang telah terdaftar. Hal tersebut peneliti temukan pada saat melakukan wawancara kepada Ibu Khodijah.

Selanjutnya, berdasarkan hasil wawancara dan observasi di

\footnotetext{
14 Wawancara Pribadi dengan Pak Mahmudin selaku Plt. Kasi. Kesos. Kecamatan Setu pada tanggal 23 September 2019 pada pukul 10.00 WIB

EISSN:2580-0973 | ISSN: 2580-085X
} 
lapangan, terdapat pihak-pihak lain yang terlibat pada program ini, seperti Dinas Pertanian Kota Tangerang Selatan dan juga dari lembaga pendidikan kampus serta para praktisi pengusaha yang berkaitan dengan usaha rumahan. Sehingga peran yang dijalankan oleh para pihak tersebut sebagai tenaga ahli (expert). Hal tersebut peneliti temukan saat melakukan wawancara dengan Ibu Khodijah, beliau mengatakan bahwa: ${ }^{15}$

"Saat pelatihan itu, pematerinya kita datangkan dari Dinas Pertanian Kota. Selain itu, kami juga mengundang pemateri dari kampus juga pengusaha yang sudah menggeluti dunia usaha sangat lama. Waktu itu kami mengundang dosen dari Institut Teknologi Indonesia (ITI). Kalau dosen paling kita minta tolong buat materi secara konsepnya saja. Kalau pengusaha, karena emangsesama pengusaha itu bisa menggunakan sistem sharingpengalaman."

\section{Analisis Peran Pelaksana dan Program UP2K}

Menurut Zastrow yang di kutip oleh Abu Huraerah (2008: 149) peran petugas pengembangan masyarakat adalah: 1) Enabler (pemercepat perubahan), 2) Broker (perantara), 3) Educator (pendidik), 4) Expert (tenaga ahli), 5) Social Planner (perencana sosial), 6) Advocate (advokasi), dan 7) Activist (aktivis).

Berdasarkan hasil wawancara dan observasi, ada beberapa peran yang dimainkan oleh pelaksana maupun program itu sendiri. UP2K merupakan program yang berfungsi sebagai pemercepatan perubahan sosial (enabler), kemudian para pihak yang terlibat pada pelaksanaannya, berperan sebagai perantara (broker), pendidik (educator), tenaga ahli (expert), dan perencana sosial (social planner). Adapun penjelasannya, sebagai berikut:

\section{Sebagai Pemercepat Perubahan (Enabler)}

UP2K merupakan program yang berfungsi sebagai pemercepatan perubahan sosial (enabler). Namun program ini tidak akan berjalan dengan maksimal jika subjek pelaksananya tidak paham akan peran dari program tersebut. Berdasarkan hasil wawancara dengan Pak Mahmudin, pihak kecamatan berperan sebagai monitoring program dan kelurahan sebagai

\footnotetext{
${ }^{15}$ Ibid

EISSN:2580-0973 I ISSN: 2580-085X
} 
perantara dan juga pelaksana program. ${ }^{16}$

Sehingga untuk peran sebagai pemercepat perubahan, pihak yang menjalankan peran tersebut adalah kelurahan, dalam hal ini dilakukan oleh Ibu Lurah yaitu Bu Mayuni. Tugas yang dilakukan oleh Bu Lurah agar masyarakt dapat mengetahui akan kebutuhan mereka, kemudian mengidentifikasi masalah yang terjadi, serta membantu pengembangan kapasitas masyarakt agar bisa mengahadapi masalah dengan efektif.

Menurut Zastrow yang dikutip oleh Abu Huraera17, ada empat fungsi utama yang dilakukan pengembang masyarakat sebagai pemercepat perubahan (enabler), yaitu membantu masyarakat menyadari dan melihat kondisi mereka, membangkitkan dan mengembangkan organisasi dalam masyarakat, mengembangkan relasi yang baik, dan memfasilitasi perencanaan yang baik.

Peneliti menganalisis bahwa peran pemercepat perubahan yang dijalankan oleh kelurahan sudah cukup terlihat dengan baik. Kelurahan membantu masyarakat untuk sadar akan kondisinya. Kemudian kelurahan juga berperan aktif untuk membangkitkan dan mengembangkan organisasi PKK yang menjadi ujung tombak dari Program UP2K ini.

Mengenai pengembangan relasi, kelurahan menjalankan perannya dengan baik dalam membangun relasi dengan instansi lain yang bisa berkaitan dengan kebutuhan akan pengembangan skill anggota program. Kemudian kelurahan juga melakukan perkumpulan yang bertujuan mengevaluasi dan merencanakan dengan berbagai pihak. Relasi yang dibuat oleh pihak kelompok PKK diantaranya relasi para pengusaha pada tingkat kelurahan yang semakin membaik. Misalnya apabila ada salah seorang pengusaha yang kesulitan untuk memenuhi permintaan dari konsumen, bisa ikut membantu yang kemudian membagi hasil pendapatannya.

Kemudian relasi lain yang sudah terjalin dengan baik adalah relasi antara para pengusaha di Kelurahan Setu dengan pihak Pemerintah Kota Tangerang Selatan. Hal tersebut peneliti peroleh saat mewawancarai Ibu Khodijah dan Ibu Saumi yang menyatakan bahwa para pengusaha di

\footnotetext{
${ }_{16}$ Wawancara Pribadi dengan Pak Mahmudin selaku Plt. Kasi. Kesos. Kecamatan Setu pada tanggal 23 September 2019 pada pukul 10.00 WIB

17 A. Huraerah, Pengorganisasian Dan Pengembangan Masyarakat: Model Dan Strategi

Pembangunan Berbasis Kerakyatan (Bandung, 2010).
}

EISSN:2580-0973 I ISSN: 2580-085X 
Kelurahan Setu sering diundang setiap acara yang berkaitan dengan pengusaha, seperti bazar bagi para pengusaha kecil dan menengah. Selain itu, pada saat pertama kali program ini digulirkan, pihak Kelurahan Setu dan PKK melakukan kerja sama dengan Dinas Pertanian Kota Tangerang Selatan serta dengan Kampus Institut Teknologi Indonesia.

\section{Peran Sebagai Perencana Sosial (Social Planner)}

Pada peran sebagai perencana sosial, biasanya berkaitan dengan individu. Individu yang berperan mengumpulkan fakta-fakta tentang masalah sosial yang terdapat dalam komunitas serta menyusun alternatif tindakan dalam menangani masalah tersebut. Seorang sosial planner lebih lebih memfokuskan pada keterlibatan dalam tugas-tugas pengembangan dan pengimplementasian program.

Berdasarkan hasil data yang diperoleh, peran perencana sosial pada program UP2K ini dilakukan oleh Ibu Mayuni, selaku Ibu Lurah di Kelurahan Muncul. Hal tersebut diperkuat oleh hasil wawancara yang telah dilakukan, peneliti menemukan bahwa peran tersebut memang dilakukan oleh Ibu Mayuni. Selain Ibu Mayuni, peran sebagai perencana sosial juga dilakukan oleh Ibu Khodijah. Namun peran yang dilakukan berebeda. Jika Ibu Mayuni merencanakan dan memantau pelaksanaan, sementara Ibu Khodijah berperan sebagai perencana sosial dan juga pelaksananya.

Peran sebagai perencana sosial ini dapat dilihat ketika UP2K-PKK melakukan rapat di awal tahun dan di akhir tahun. Saat rapat di awal tahun, merupakan rapat yang dilakukan untuk merencakan apa saja yang menjadi target untuk program tersebut. Sementara untuk rapat akhir tahun dilakukan berkaitan dengan evaluasi dari capaian-capaian yang sudah dicapai dan apa saja yang perlu dilakukan.

\section{Peran Sebagai Pendidik (Educator)}

Dalam menjalankan peran sebagai pendidik, pengembang masyarakat diharapkan mempunyai kemampuan menyampaikan informasi dengan baik dan jelas, serta mudah ditangkap oleh komunitas yang menjadi sasaran perubahan. Di samping itu, ia juga harus mempunyai pengetahuan yang cukup memadai mengenai topik yang akan dibicarakan. Aspek lain yang terkait dengan peran ini adalah keharusan bagi seorang pengembang 
masyarakat untuk selalu belajar.

Berdasarkan hasil wawancara yang sudah dipaparkan sebelumnya, bahwa pada pelaksanaan peran sebagai pendidik ini dijalankan oleh kelurahan, bekerjasama dengan berbagai elemen, seperti ibu-ibu yang aktif di PKK, kemudian beberapa instansi yang bisa membantu untuk meningkatkan kemampuan dari masyarakat sebagai pengusaha rumahan.

Ada beberapa pihak yang pernah diajak bekerjasama oleh Kelurahan Muncul, seperti Dinas Pertanian, Institut Teknologi Indonesia (ITI), mahasiswa dari kampus Universitas Islam Negeri (UIN) Syarif Hidayatullah Jakarta yang kadang memberikan materi tentang wirausaha ketika melakukan penelitian, serta mengundang para pengusaha rumahan lain namun yang sudah mapan untuk berbagi ilmu.

Selanjutnya, para pengusaha yang sudah mendapatkan pelatihan tersebut membantu para pengusaha lain yang baru menjadi anggota UP2K. Materi yang diberikan seperti pengemasan produk, pemasaran produk, serta penggunaan barang-barang limbah menjadi bernilai. Kelurahan juga sering memberikan informasi jika ada perlombaan atau memberikan arahan jika ada informasi yang kurang tepat di masyarakat terkait dengan program UP2K.

\section{Peran Sebagai Perantara (Broker)}

Untuk peran sebagai perantara ini, erat kaitannya dengan hubungan individu-individu ataupun kelompok dalam masyarakat yang membutuhkan pertolongan dengan pelayanan masyarakat, akan tetapi tidak tahu dimana dan bagaimana mendapatkan bantuan tersebut dengan lembaga yang menyediakan layanan masyarakat. Secara sederhana, peran sebagai perantara itu seperti seorang mediator dalam hal pengembangan atau pemberdayaan masyarakat.

Peran sebagai perantara ini dijalankan oleh kelurahan. Dalam menjalankan perannya sebagai perantara, kelurahan menghubungkan para individu-individu maupun kelompok pengusaha rumahan yang membutuhkan pertolongan ataupun layanan masyarakat. Secara umum, terdapat 2 (dua) cara yang digunakan oleh kelompok PKK. Pertama cara yang digunakan adalah dengan mengelompokkan para pengusaha tersebut berdasarkan jenis usaha yang jalankan. Setelah dikelompokkan, para 
pengusaha tersebut bisa saling bekerjasama apabila mengalami kendala yang tidak bisa diselesaikan.

Cara kedua yang digunakan kelurahan saat menjalankan perannya sebagai perantara adalah dengan cara melakukan kontak dengan pejabat yang secara hierarki lebih tinggi, seperti Pemerintah Kota Tangerang Selatan, maupun para aparatur kelurahan sekitar untuk saling membantu. Hal tersebut pernah dilakukan oleh kelompok PKK yang menjalin relasi dengan Dinas Pertanian Kota Tangerang Selatan. Selain itu kelompok PKK Kelurahan Muncul pernah juga membangun relasi dengan kampus Institut Teknologi Indonesia yang berada tidak jauh dari lokasi penelitian.

Maka menurut peneliti, apa yang telah dilakukan oleh kelurahan dalam menjalankan perannya sebagai perantara sudah berjalan dengan baik. Dengan menghubungkan para pengusaha secara individu, maupun secara kelompok, membuat para pengusaha tersebut lebih mudah dalam mengembangkan usahanya.

\section{Analisis Dampak Program UP2K}

Berdasarkan hasil observasi, data, dan wawancara yang telah dilakukan, dampak dari program UP2K ini dapat dilihat berdasarkan aktivitas yang telah dilakukan dari tahap awal hingga akhir.

Tahap pertama dari program ini adalah perencanaan program. Pada tahap ini, para penanggung jawab seperti kelurahan dan kelompok PKK melakukan rapat dan menghasilkan beberapa perencanaan target untuk satu tahun pelaksanaan. Jika menggunakan pendekatan Logical Framework Approach maka dampak yang ingin dituju dari program ini adalah pemberdayaan usaha mikro, kecil, dan menengah dengan kaum perempuan sebagi pelaku usahanya, baik secara pribadi atau kelompok. Dengan tujuan untuk meningkatkan pendapatan atau perekonomian keluarga.

Sementara untuk strategi yang digunakan oleh Kelurahan Muncul adalah dengan pendekatan kolektif. Ibu Lurah memiliki peran yang sangat vital pada pennetuan langkah yang akan dilakukan oleh Kelompok Kerja (Pokja). Misalnya seperti mengunjungi tempat usaha, metode pembayaran yang mudah, serta cara mempromosikan program saat pertama kali turun.

Sehingga terdapat beberapa dampak yang dapat dirasa oleh para pengurus maupun pengusaha yang ikut bergabung pada UP2K. 
Diantaranya administrasi yang lebih rapih, sehingga pengurus lebih mudah untuk mengetahui siapa saja yang membuka usaha di rumahnya, jumlah usaha rumahan, jenis usaha yang dibuka, serta untuk pengelompokkannya.

Terdapat 30 pengusaha yg terdata di kelurahan dan dikelompokan menjadi 4 (empat) bagian, yaitu kelompok pertama untuk pengusaha yang membuka usaha kue kering dengan jumlah 11 orang. Kelompok kedua yang berisi pengusaha rumahan kue basah, sebanyak 5 orang. Kelompok ketiga, kerajinan tangan sebanyak 8 orang, Dan terakhir kelompok usaha campuran, terdiri dari pedagang kopi keliling, warung nasi, bakso, dan lain lain sebanyak 6 orang.

Tabel I. Kelompok Usaha Melati

\begin{tabular}{ccc}
\hline No & Nama & Jenis Usaha \\
\hline 1 & Mulyani & Kue Kering \\
2 & Asmiyati & Kue Kering \\
3 & Suryanah & Kue Kering \\
4 & Jumiyati & Kue Kering \\
5 & Asmah & Kue Kering \\
6 & Mirsah & Kue Kering \\
7 & Anisa & Kue Kering \\
8 & Sopiah & Kue Kering \\
9 & Nunong & Kue Kering \\
10 & Sari Asih & Kue Kering \\
11 & Dedeh & Kue Kering \\
\hline
\end{tabular}

Tabel 2. Kelompok Usaha Cemara

\begin{tabular}{ccc}
\hline No & Nama & Jenis Usaha \\
\hline 1 & Mirhamah & Kopi \\
2 & Rodiyah & Gado-Gado \\
3 & Nurhayati & Bakso \\
4 & Soliah & Warung Nasi \\
5 & Saodah & Minuman \\
6 & Istiyah & Campuran \\
\hline
\end{tabular}


Tabel 3. Kelompok Usaha Mawar

\begin{tabular}{ccc}
\hline No & Nama & Jenis Usaha \\
\hline 1 & Nurhati & Kue Basah \\
2 & Awinah & Kue Basah \\
3 & Ningrum & Kue Basah \\
4 & Mini & Kue Basah \\
5 & Suryati & Kue Basah \\
\hline
\end{tabular}

Tabel 4. Kelompok Usaha Anggrek

\begin{tabular}{ccc}
\hline No & Nama & Jenis Usaha \\
\hline 1 & Nurhayati & Aksesoris \\
2 & Rani & Aksesoris \\
3 & Ade Irma & Aksesoris \\
4 & Ijah & Aksesoris \\
5 & Ikah & Aksesoris \\
6 & Tinah & Aksesoris \\
7 & Ayati & Aksesoris \\
8 & Hakim & Kerajinan Tangan \\
\hline
\end{tabular}

Dampak pengelompokkan usaha memberikan kemudahan bagi pengusaha lainnya. Apabila pada saat proses pemesanan, si pengusaha merasa sulit memenuhi permintaan dari pembeli akan dibantu dari pengusaha lain. Sehingga secara tidak langsung, proses pengelompokkan tersebut mengandung sistem gotong royong.

Kemudian dampak yang sangat terasa dengan adanya program UP2K adalah secara ekonomi. Dengan menggunakan sistem peminjaman serta pengembalian yang mudah, sangat membantu para pengusaha. Para pengusaha yang berpartisipasi bisa menabung dari hasil pendapatan tersebut. Bahkan uang pengembalian usaha yang diberikan kepada pelaksana, bisa dijadikan tabungan apabila memberikan uang pengembalian yang lebih. Dan dampak yang tidak kalah pentingnya adalah membuat masyarakat lebih mengurangi melakukan peminjaman kepada bank keliling. 


\section{Analisis Faktor Pendukung dan Penghambat Program UP2K}

Untuk dapat mengetahui faktor pendukung dan penghambat pelaksanaan program, salah satu cara yang dapat membantu menginventarisir berbagai persoalan adalah dengan menggunakan pendekatan Logical Framework Approach (LFA). Logical Framework Approach (LFA) adalah alat untuk perencanaan, monitoring dan evaluasi dari project/program.

Selain itu LFA adalah instrumen analisis, presentasi, dan manajemen yang dapat membantu perencana untuk menganalisis situasi eksisting, membangun hierarki logika dari tujuan yang akan dicapai, mengidentifikasi resiko potensial yang dihadapi dalam pencapaian tujuan dan hasil, membangun cara untuk melakukan monitoring dan evaluasi terhadap tujuan (output) dan hasil (outcome), menyajikan ringkasan aktivitas suatu kegiatanserta membantu upaya monitoring selama pelaksanaan implementasi proyek.

Berdasarkan hasil wawancara bahwa terdapat beberapa faktor yang mendukung program UP2K ini dapat berjalan dengan baik. Adapun faktor pendukung dari kegiatan tersebut diantaranya; Pertama, dukungan dari pihak kelurahan terhadap pelaksanaan program UP2K yaitu ketika kelompok usaha mengikuti perlombaan pada tingkat kota di Tangerang Selatan.

Kedua, adalah sarana dan prasarana yang mendukung seperti jarak tempat usaha yang satu dengan yang lainnya tidak begitu jauh. Sehingga membuat para pelaksana lebih mudah untuk mengaksesnya dan saling berkomunikasi apabila ada pesanan dari kelurahan. Adanya aula tempat anggota dan kelompok pelaksana untuk berkumpul juga menjadi faktor yang mendukung.

Ketiga adalah semangat dari masyarakat yang tinggi. Masyarakat di Kelurahan Muncul memiliki keinginan yang kuat untuk hidup lebih baik lagi dari segi ekonomi dan sangat antusias, sehingga memudahkan para pelaksana untuk melaksanakan program ini.

Mengenai faktor penghambat dari program ini diantaranya; Pertama, pembayaran yang tidak tepat waktu. Dengan tersendatnya pembayaran peminjaman, membuat pengusaha lain yang ingin mengajukan pinjaman harus menunggu.

Kedua, tidak adanya penghargaan bagi para pengusaha yang EISSN:2580-0973 I ISSN: 2580-085X 
menjadi anggota dan memenangkan perlombaan di berbagai tingkatan. Ketika pengusaha yang sudah mewakili Kelurahan Muncul akan tetapi tidak mendapatkan uang hadiah tersebut.

Ketiga, besaran jumlah pinjaman yang tidak mengalami peningkatan. Apabila dapat meningkatkan jumlah besaran pinjaman yang diberikan, besar kemungkinan program ini akan lebih cepat dikenal dan tujuan program lebih cepat tercapai.

Keempat, tidak adanya pergantian pada kepengurusan. Pergantian kepengurusan seharusnya terjadi untuk kelompok pelaksana program ini sebab berpeluang melahirkan program-program yang lebih inovatif dari pada pengurus sebelumnya.

\section{SIMPULAN}

Beberapa kesimpulan berkaitan dengan riset ini sebagai berikut: Pertama, pada pelaksanaannya, program ini banyak melibatkan para petugas dari Kelurahan Muncul. Sehingga para petugas kelurahan tersebut, sebenarnya sedang menjalankan fungsi pelayanan, fungsi pengaturan, dan fungsi pemberdayaan. Kemudian untuk peran yang dijalankan oleh para pelaksana program ini diantaranya sebagai enabler (pemercepat perubahan), broker (perantara), educator (pendidik), dan social planner (perencana sosial).

Kedua, mengenai dampak dari Program UP2K diantaranya secara administrasi para pengusaha yang ada di Kelurahan Muncul terdata dengan mudah, terbentuknya kelompok usaha, dan berkurang jumlah warga yang melakukan peminjaman kepada bank keliling.

Ketiga, faktor pendukung diantaranya dukungan yang kuat dari pihak Kelurahan Muncul, sarana dan prasarana, dan semangat dari masyarakat yang begitu tinggi. Sedangkan faktor penghambat diantaranya metode pembayaran yang tidak ketat, tidak adanya hadiah bagi para pengusaha yang yang berprestasi, besaran jumlah pinjaman yang tidak mengalami pengembangan, dan tidak adanya pergantian pada kepengurusan.

Sebagai suatu program, UP2K memiliki beberapa kekurangan pada tahap pelaksanaanya. Beberapa saran dan rekomendasi untuk perbaikan program pada masa mendatang sebagai berikut:

Pertama, untuk masyarakat Kelurahan Muncul agar meningkatkan 
kerjasama yang baik diantara semua pihak yang terlibat. Sejauh ini program UP2K sudah berjalan dengan baik, namun kendala seperti macetnya pembayaran pengembalian pinjaman bisa menjadi faktor penghambat. Maka apabila masyarakat melakukan peminjaman, segera tuntaskan pengembalian pinjaman tersebut.

Kedua, saran kepada pelaksana program, akan lebih berkembang lagi apabila besaran nominal pinjaman uang juga diperbesar dan harus ada pergantian kepengurusan dalam tubuh organisasi pelaksanaannya. Sebab dengan pergantian pengurus, besar kemungkinan untuk mengembangkan program ini menjadi lebih inovatif.

\section{DAFTAR PUSTAKA}

Apriliza, Diana, 'Faktor-Faktor Penghambat Dalam Pelaksanaan Program

Pemberdayaan Keluarga Untuk Orang Tua Anak Jalanan (Studi Kasus

Pada Orang Tua Penerima Bantuan Stimulan Modal Usaha Pada Pusat

Pengembangan Pelayanan Sosial Anak/P3SA Bambu Apus' (Universitas

Indonesia, 2012)

Asripah, Siti, 'Peranan Posdaya Dalam Meningkatkan Kesejahteraan Keluarga

Di Masyarakat', DEMOCRATIA, 1.1 (2013)

Emzir, Metodologi Penelitian Kualitatif (Jakarta: Rajawali Pers, 2011)

Huraerah, A., Pengorganisasian Dan Pengembangan Masyarakat: Model Dan

Strategi Pembangunan Berbasis Kerakyatan (Bandung, 2010)

Itang, Itang, 'Faktor Faktor Penyebab Kemiskinan', Tazkiya, 16.01 (2017), 1-30

Moleong, Lexy J, Metode Penelitian Kualitatif (Bandung: PT Remaja Rosdakarya, 2011)

'No Title', Tangerangexpres.Co.Id, 20 January 2019

Nurdin, Muhammad, Sitti Nurmaeta, and Muhammad Tahir, 'Peran

Pemerintah Daerah Dalam Pemberdayaan Masyarakat Petani Jagung Di

Kecamatan Biringbulu Kabupaten Gowa', Otoritas: Jurnal Ilmu

Pemerintahan, 4.1 (2014)

Statistik, Badan Pusat, 'No Title'

<www.bps.go.id/pressrelease/2019/01/15/1549/persentate-penduduk-

miskin-pada- september-2018-sebesar-9-66-persen.html> [accessed 20

January 2019]

Strategi Pemberdayaan Masyarakat (Edisi Revisi) (Bandung: Utama Press, 2010) Suharyanto, Motivasi Masyarakat Untuk Pengembangan Kewirausahaan, Dalam EISSN:2580-0973 I ISSN: 2580-085X 
Dimensi-Dimensi Masalah Sosial Dan Pemberdayaan Masyarakat (Yogyakarta: APMD Press, 2005)

Wawancara Pribadi dengan Bapak Mahmudin Pada Tanggal 23 September 2019 Pada Pukul 10.00 WIB di Kantor Kecamatan Setu, Kota Tangerang Selatan

Wawancara Pribadi dengan Ibu Khodijah pada tanggal 27 September 2018 pada pukul 14.00 WIB di Kantor Kelurahan Muncul, Kec. Setu, Kota Tangerang Selatan 